\title{
Tinjauan Pengalihan Kewenangan Guru Tidak Tetap/Pegawai Tidak Tetap (GTT/PTT) Pendidikan Menengah dari Pemerintah Kabupaten/Kota Ke Pemerintah Provinsi Jawa Tengah
}

\author{
Ary Widyastuti ${ }^{1}$; Kismartini $^{2}$; Retno Sunu Astuti ${ }^{3}$ \\ 1,2,3Program Magister Administrasi Publik, Universitas Diponegoro Semarang, \\ widya.4ry@gmail.com, kis_martini@yahoo.com, retnosunu@yahoo.com
}

\begin{abstract}
Abstrak
Pengalihan kewenangan pengelolaan pendidikan menengah dari Pemerintah Kabupaten/Kota ke Pemerintah Provinsi Jawa Tengah membawa dampak yang sangat besar bagi Guru Tidak Tetap (GTT) dan Pegawai Tidak Tetap (PTT) antara lain status kepegawaian dan kesejahteraan yang semula kewenangannya menjadi tanggung jawab Pemerintah Kabupaten/Kota beralih ke Pemerintah Provinsi. Tujuan penelitian ini untuk mendeskripsikan dan menganalisis pengalihan kewenangan pengelolaan GTT dan PTT pendidikan menengah dari Pemerintah Kabupaten/Kota ke Pemerintah Provinsi Jawa Tengah serta faktor-faktor yang mempengaruhi pengalihan kewenangan tersebut. Penelitian ini merupakan penelitian deskriptif kualitatif dengan teknik pengumpulan data melalui wawancara, observasi dan dokumentasi. Hasil penelitian bahwa pengalihan kewenangan pengelolaan GTT dan PTT pendidikan menengah dari Pemerintah Kabupaten/Kota ke Pemerintah Provinsi Jawa Tengah dilaksanakan dengan baik. Faktorfaktor yang memengaruhi antara lain jumlah pelaksana yang memadai dan kompetensi sesuai, ketersediaan anggaran yang memadai, ketersediaan peralatan dan teknologi yang mendukung namun karena rentang kendali Dinas Pendidikan dan Kebudayaan Provinsi Jawa Tengah yang besar dalam pelayanan administrasi pengelolaan GTT dan PTT belum optimal.
\end{abstract}

Kata kunci : Desentralisasi Pendidikan, Pengalihan kewenangan, GTT, PTT

\begin{abstract}
The transfer of authority for the management of secondary education from Regency/Municipal Governments to the Central Java Provincial Government has had a huge impact on Temporary Teachers (GTT), and Temporary Employees (PTT), including employment status and welfare, which were previously the responsibility of the Regency/Municipal Government to Provincial Government's purpose of this study is to describe and analyze the transfer of authority to manage secondary education GTT and PTT from the Regency/Municipal Government to Provincial Government and the factors that influence this transfer of authority. This research method is a qualitative descriptive study with data collection techniques through interviews, observation, and documentation. The results showed that the transfer of authority for the management of secondary education Regency/Municipal Government to the Central Jawa Government was implemented properly. The factors that influence include an adequate number of implementers and appropriate competence, availability of budget, availability of supporting equipment and technology but due to the large range of control of the Central Java Province Education and Culture Office in administrative service, the management of GTT and PTT is not optimal. Keywords: Decentralization of education, Transfer authority, GTT, PTT
\end{abstract}




\section{Pendahuluan}

Pengalihan kewenangan pengelolaan pendidikan menengah ini membawa dampak yang sangat besar bagi Guru Tidak Tetap (GTT) dan Pegawai Tidak Tetap (PTT) antara lain status kepegawaian dan tingkat kesejahteraan yang semula kewenangannya menjadi tanggung jawab Pemerintah Kabupaten/Kota beralih ke Pemerintah Provinsi. Selain itu juga berdampak pada proses pengawasan dan monitoring sekolah dimana GTT dan PTT bekerja.

Dari jumlah GTT dan PTT di Provinsi Jawa Tengah sebesar 14.638 orang, Kota Semarang yang terbesar di antara 35 Kabupaten/Kota lainnya di Provinsi Jawa Tengah sebanyak 772 orang. GTT dan PTT yang dialihkan dari Pemerintah Kabupaten/Kota tidak semuanya dapat menjadi GTT dan PTT Pemerintah Provinsi Jawa Tengah sebagaimana pendidik dan tenaga kependidikan PNS yang statusnya beralih dari PNS Pemerintah Kabupaten/Kota menjadi PNS Pemerintah Provinsi Jawa Tengah. GTT dan PTT yang pada saat pengalihan kewenangan sudah terdaftar sebagai GTT dan PTT dan terikat kontrak individu dengan Dinas Pendidikan dan Kebudayaan Provinsi Jawa Tengah yang berhak mendapatkan status dan honorarium dari Pemerintah Provinsi Jawa Tengah sesuai ketentuan dengan Peraturan Gubernur Jawa Tengah Nomor 3 Tahun 2017. Sedangkan GTT dan PTT yang belum terdaftar pada saat pengalihan kewenangan belum diatur dalam Peraturan Gubernur Jawa Tengah Nomor 3 Tahun 2017. Pasca pengalihan kewenangan pengelolaan pendidikan menengah tersebut banyak pendidik dan tenaga kependidikan ASN yang pensiun dan belum ada pengangkatan ASN baru sehingga direkrut GTT dan PTT agar proses pendidikan terus berlangsung.

Pengalihan kewenangan pengelolaan pendidikan menengah dari Pemerintah Kabupaten/Kota ke Pemerintah Provinsi Jawa Tengah merupakan salah satu kebijakan desentralisasi pendidikan untuk memudahkan pemerintah provinsi dalam menyeragamkan kebijakan pengelolaan pendidikan dan kebijakan ini diharapkan dapat meningkatkan akuntabilitas serta efektivitas kebijakan pendidikan dalam rangka good governance (Sendhikasari, 2016).

Istilah desentralisasi menurut Huda (dalam Hermino, 2014) mengandung makna proses pendelegasian atau pelimpahan kekuasaan atau wewenang dari 
pimpinan atau atasan ke tingkat bawahan dalam organisasi. Melalui desentralisasi, segala keputusan yang dibuat di dalam organisasi didelegasikan kepada bawahan. Desentralisasi kewenangan bertujuan untuk meningkatkan kemampuan dan kemandirian organisasi yang ada di level yang lebih rendah, sebagai bagian dari upaya pemberdayaan organisasi pelaksana pada level yang lebih rendah. Dalam konteks pelayanan publik, desentralisasi kewenangan dimaksudkan untuk mendekatkan pelayanan kepada publik, agar dapat lebih cepat pelayanan itu sampai kepada masyarakat, guna meningkatkan kesejahteraan masyarakat.

Desentralisasi kewenangan dilihat dalam perspektif manajerial terdapat beberapa versi dalam pengkategorian model desentralisasi. Model-model itu dikemukakan oleh berbagai ahli antara lain Rondinelli dan Cheema (dalam Sarundajang, 2005). Menurut Rondinelli dan Cheema, dalam perpektif manajerial terdapat 4 (empat) model desentralisasi dari pusat ke daerah, yaitu: Model devolusi, yakni bila kewenangan dari Pemerintah Pusat diberikan kepada Pemerintah Daerah. Model ini dilaksanakan dengan pembentukan daerah otonom dan pemberian otonomi serta dibentuknya lembaga daerah dan DPRD. Model dekonsentrasi, yaitu bila kewenangan dilimpahkan kepada pejabat-pejabat pusat yang ditugaskan di daerah. Pada kebijakan dekonsentrasi ini lembaga lembaga yang dibentuk disebut instansi vertikal dan wilayah kerjanya disebut wilayah administratif yang mencakup satu atau lebih wilayah daerah otonom. Model delegasi, yaitu model ini dilakukan bila Pemerintah Pusat mendelegasikan pelaksanaan suatu tugas tertentu kepada suatu lembaga atau unit pemerintahan yang khusus dibentuk untuk keperluan tertentu. Contoh model ini adalah pembentukan BUMN dalam berbagai sektor. Model privatisasi, dengan model ini untuk kepentingan efisiensi yaitu mengurangi beban penyediaan pelayanan publik yang diberikan oleh Pemerintah, diserahkan pengelolaannya kepada swasta murni dengan pemberian izin dan pengendalian dalam batas tertentu, seperti pembentukan sekolah swasta, rumah sakit swasta, pasar swasta (mall), jalan tol dan sebagainya.

Menurut Burki (dalam Hermino, 2014), secara konseptual, terdapat dua jenis desentralisasi pendidikan, yaitu: pertama, desentralisasi kewenangan di sektor pendidikan daerah dalam hal kebijakan pendidikan dan aspek pendanaannya dari 
pemerintah pusat kepada pemerintah daerah (provinsi dan distrik) dan kedua, desentralisasi pendidikan dengan fokus pada pemberian kewenangan yang lebih besar di tingkat sekolah. Konsep desentralisasi pendidikan yang pertama berkaitan dengan otonomi daerah, sedangkan konsep desentralisasi dan desentralisasi penyelenggaraan pemerintahan dari pusat ke daerah, sedangkan konsep desentralisasi pendidikan yang memfokuskan pada pemberian kewenangan yang lebih besar di tingkat sekolah dilakukan dengan motivasi untuk meningkatkan kualitas pendidikan.

Jadi tujuan desentralisasi adalah pemberian kewenangan di sektor pendidikan yanag lebih besar kepada pemerintah daerah sehingga fokus desentralisasi pendidikan yang dilakukan pada pelimpahan kewenangan yang lebih besar kepada pemerintah lokal dan untuk mengurangi campur tangan atau intervensi pejabat atau unit pusat terhadap persoalan-persoalan pendidikan yang sepatutnya bisa diputuskan dan dilaksanakan oleh unit tataran bawah, pemerintah daerah, atau masyarakat sehimgga diharapkan terjadi pemberdayaan peran unit di bawah atau peran rakyat dan masyarakat daerah.

Kewenangan atau wewenang adalah suatu istilah yang biasa digunakan dalam area hukum publik. Kewenangan adalah apa yang disebut "kekuasaan formal”, kekuasaan yang berasal dari kekuasaan yang diberikan oleh UndangUndang atau legislatif dari kekuasaan eksekutif atau administratif karenanya kekuasaan dari segolongan orang tertentu atau kekuasaan terhadap suatu bidang pemerintahan atau urusan pemerintahan yang bulat. Sedangkan wewenang hanya mengenai suatu bagian tertentu saja dari kewenangan. Wewenang (authority) adalah hak untuk memberi perintah dan kekuasaan untuk meminta dipatuhi. Setiap perbuatan pemerintahan harus bertumpu pada suatu kewenangan yang sah. Oleh karena itu kewenangan yang sah merupakan atribut bagi setiap pejabat ataupun lembaga.

Menurut Lufti Effendi (2003) kewenangan yang sah jika ditinjau darimana kewenangan itu diperoleh terbagi atas tiga kategori kewenangan, yaitu atributif, mandat dan delegatif. Dalam desentralisasi dan otonomi daerah, hubungan antara pemerintah pusat dengan daerah sangat dipengaruhi oleh model dan besaran 
kewenangan yang dibagi. Pembagian kewenangan ini dapat dijadikan cara untuk mengharmonisasi hubungan pusat - daerah sehingga pemerintahan dapat berjalan dengan baik.

Gabriel U. Iglesias (dalam Josef Riwu Kaho, 2010) menyatakan bahwa keberhasilan pelaksanaan penyerahan kewenangan kepada daerah otonomi ditentukan oleh lima faktor yang mempengaruhi pelaksanaan otonomi daerah yaitu sumber daya, struktur, teknologi, daya dukung, dan kepemimpinan. Sedangkan menurut Kaho (2010) faktor-faktor yang mempengaruhi penyelenggaraan otonomi daerah dan yang sangat menentukan prospek otonomi daerah pada masa yang akan datang antara lain pelaksananya harus baik, keuangan yang baik, peralatan yang cukup dan baik, serta organisasi dan manajemen yang baik pula.

Berdasarkan penelitian terdahulu oleh RE Setia (2019) implementasi kebijakan pengalihan pendidikan menengah ke provinsi sudah berjalan dengan baik dilihat dari variabel tata kelola pendidik dan tenaga kependidikan mulai dari rekrutmen, pembinaan hingga pemberhentian dan pensiun. Pemenuhan kebutuhan GTK dilakukan dengan mengangkat GTT dan PTT honorer menjadi pegawai provinsi dan rekrutmen pendidik dan tenaga kependidikan menjadi kewenangan masing-masing sekolah untuk menyusun kebutuhan GTT dan PTT. Pembinaan PTK dilakukan melalui pengembangan kualitas dan kapasitas, pemberian kesejahteraan dan pengawasan kinerja PTK, sedangkan untuk pemberhentian dan pensiun PTK PNS sesuai dengan batas usia yang telah diatur Undang-Undang sedangkan untuk GTT dan PTT pemberhentian nya atau pemutusan hubungan kerja berdasarkan kontrak kerja.

Sedangkan Nunik Retno Herawati (2017) menyatakan dengan alih kewenangan pendidikan menengah dari Pemerintah Kabupaten/Kota ke Pemerintah Provinsi maka Guru dan Tenaga kependidikan SMA dan SMK yang semula berstatus PNS Pemerintah Kabupaten/Kota dialihkan menjadi Pegawai Negeri Sipil Daerah Provinsi dan Pemerintah Provinsi akan memiliki kewenangan dalam hal mengatur (policy making) dalam seleksi, rekruitmen, pengangkatan, penempatan, mutasi PNS khususnya Guru dan Kepala Sekolah. Dengan sentralisasi kewenangan 
di tingkat Pemerintah Provinsi maka kesewenangan-wenangan Kepala Daerah Bupati/Kota dalam pengelolaan Guru bisa diminimalisir pada pelaksanaan Pilkada.

Berdasarkan latar belakang dan penelitian terdahulu maka artikel ini bertujuan untuk mendeskripsikan dan menganalisis pengalihan kewenangan pengelolaan GTT dan PTT pendidikan menengah dari Pemerintah Kabupaten/Kota ke Pemerintah Provinsi Jawa Tengah serta menganalisis faktor-faktor yang memengaruhi pengalihan kewenangan tersebut..

\section{Metode}

Penelitian ini menggunakan metode penelitian deskriptif kualitatif. Bungin (2012: 67) mengemukakan bahwa desain penelitian kualitatif terdiri dari tiga model yaitu deskriptif, verifikatif, dan grounded theory. Fokus penelitian ini adalah pengalihan kewenangan pengelolaan GTT dan PTT pendidikan menengah dari Pemerintah Kabupaten/Kota ke Pemerintah Provinsi Jawa Tengah serta faktorfaktor yang mempengaruhi pengalihan kewenangan tersebut. Lokus penelitian di Dinas Pendidikan dan Kebudayaan Provinsi Jawa Tengah. Adapun teknik pengumpulan data menggunakan wawancara, observasi dan dokumentasi. Sedangkan teknik analisis data menggunakan teknik analisis dari Miles dan Huberman (dalam Sudirman \& Phradiansah, 2019) yaitu dengan reduksi data, penyajian data, penarikan kesimpulan dan melakukan verifikasi.

\section{Hasil dan Pembahasan}

Hasil penelitian menunjukkan bahwa pengalihan kewenangan pengelolaan GTT dan PTT pendidikan menengah dari Pemerintah Kabupaten/Kota ke Pemerintah Provinsi Jawa Tengah merupakan bentuk pelaksanaan desentralisasi pendidikan yang telah dilaksanakan dengan baik.

Pengalihan kewenangan pengelolaan pendidikan menengah dari Pemerintah Kabupaten/Kota ke Pemerintah Provinsi Jawa Tengah merupakan salah satu kebijakan desentralisasi pendidikan untuk memudahkan Pemerintah Provinsi dalam menyeragamkan kebijakan pengelolaan pendidikan dalam rangka good governance. Pengalihan kewenangan pengelolaan GTT dan PTT pendidikan 
menengah dilaksanaakan bersamaan dengan pengalihan kewenangan pendidikan menengah dari Pemerintah Kabupaten/Kota ke Pemerintah Provinsi Jawa Tengah.

Pengalihan kewenangan pengelolaan pendidikan menengah dari Pemerintah Kabupaten/Kota ke Pemerintah Provinsi Jawa Tengah dilaksanakan oleh Bupati/Walikota di wilayah Jawa Tengah kepada Gubernur Jawa Tengah. Untuk pengalihan GTT dan PTT pendidikan menengah Kabupaten/Kota dilaksanakan oleh Dinas Pendidikan Kabupaten/Kota ke Dinas Pendidikan Provinsi Jawa Tengah.

Pengalihan kewenangan pengelolaan pendidikan menengah dari Pemerintah Kabupaten/Kota ke Pemerintah Provinsi Jawa Tengah dilaksanakan pada tanggal 26 September 2016 bertempat di Gedung Ghradika Bhakti Praja J1. Pahlawan No. 10 Semarang dengan ditandatanganinya Berita Acara Serah Terima Pengalihan Personil, Sarana dan Prasarana serta Dokumen antara Gubernur Jawa Tengah dengan Bupati/Walikota Se-Jawa Tengah. Dengan demikian sejak 1 Januari 2017 pengelolaan pendidikan menengah menjadi tanggung jawab Pemerintah Provinsi Jawa Tengah termasuk di dalamnya GTT dan PTT pendidikan menengah.

Pengalihan kewenangan pengelolaan GTT dan PTT pendidikan menengah dari Pemerintah Kabupaten/Kota ke Pemerintah Provinsi Jawa Tengah yang telah dilaksanakan sejak 1 Januari 2017 telah berjalan dengan baik. Pengelolaan GTT dan PTT menjadi kewenangan Dinas Pendidikan dan Kebudayaan Provinsi Jawa Tengah. Honorarium GTT dan PTT pendidikan menengah diatur dengan Peraturan Gubernur Jawa Tengah. Karena keterbatasan anggaran maka honorarium GTT dan PTT yang dialihkan tidak semuanya dapat dibiayai oleh APBN dan APBD Provinsi Jawa Tengah sehingga ada yang dibiayai melalui pendanaan swadaya masyarakat (PSM). Pada tahun 2020 pembiayaan honorarium GTT dan PTT semuanya dari APBN dan APBD Provinsi Jawa Tengah sehingga tidak ada lagi pembiayaan dari pendanaan swadaya masyarakat (PSM).

Kebijakan pengalihan kewenangan pengelolaan GTT dan PTT pendidikan menengah dari Pemerintah Kabupaten/Kota ke Pemerintah Provinsi Jawa Tengah terkait honorarium GTT dan PTT yang dialihkan tidak semuanya dapat dibiayai oleh APBN dan APBD Provinsi Jawa Tengah karena keterbatasan anggaran 
sehingga ada yang dibiayai melalui pendanaan swadaya masyarakat (PSM). Pada tahun 2020 pembiayaan honorarium GTT dan PTT semuanya dari APBN dan APBD Provinsi Jawa Tengah sehingga tidak ada lagi pembiayaan dari pendanaan swadaya masyarakat (PSM). Honorarium GTT dan PTT diatur dengan Peraturan Gubernur Jawa Tengah. Sejak peralihan kewenangan pendidikan menengah mulai 1 Januari 2017 sampai Tahun 2020, peraturan tentang honorarium GTT dan PTT telah mengalami beberapa kali perubahan, yaitu :

1) Peraturan Gubernur Jawa Tengah Nomor 3 Tahun 2017 tentang Honorarium Bagi Guru Tidak Tetap Dan Pegawai Tidak Tetap Pada Sekolah Menengah Atas Negeri, Sekolah Menengah Kejuruan Negeri Dan Sekolah Luar Biasa Negeri Pemerintah Provinsi Jawa Tengah;

2) Peraturan Gubernur Jawa Tengah Nomor 2 Tahun 2018 tentang Perubahan atas Peraturan Gubernur Jawa Tengah Nomor 3 Tahun 2017 tentang Honorarium Bagi Guru Tidak Tetap Dan Pegawai Tidak Tetap Pada Sekolah Menengah Atas Negeri, Sekolah Menengah Kejuruan Negeri Dan Sekolah Luar Biasa Negeri Pemerintah Provinsi Jawa Tengah;

3) Peraturan Gubernur Jawa Tengah Nomor 7 Tahun 2020 tentang Honorarium Bagi Guru Tidak Tetap Dan Pegawai Tidak Tetap Pada Sekolah Menengah Atas Negeri, Sekolah Menengah Kejuruan Negeri Dan Sekolah Luar Biasa Negeri Pemerintah Provinsi Jawa Tengah.

Permasalahan GTT dan PTT yang merupakan tenaga kontrak selama ini antara lain terkait dengan penggajian bagi tenaga kontrak dimana belum ada standarisasi penggajian tenaga kontrak yang ditetapkan oleh Pemerintah sehingga dapat meminimalisir kesenjangan pendapatan antara tenaga kontrak dengan ASN. Permasalahan yang muncul di lapangan bahwa terdapat ketimpangan yang tinggi pendapatan antara tenaga kontrak dengan ASN hal ini juga terkait dengan tunjangan lain lain dan THR (Tunjangan Hari Raya) yang belum ada, sehingga tenaga kontrak hanya mendapatkan honorarium bulanan saja. Hal ini sedikit banyak memunculkan kecemburuan antara tenaga kontrak dengan ASN yang bila dibiarkan begitu saja sedikit banyak akan berdampak pada kinerja dan performa dari tenaga kontrak yang ada. Selain itu belum ada kejelasan dan kepastian terkait masa depan dari tenaga 
kontrak pasca berlakunya Peraturan Pemerintah Nomor 49 Tahun 2018, Pemerintah Daerah dilarang mengangkat Pegawai Non PNS dan/atau Non PPPK (pegawai yang saat ini dikenal dengan sebutan tenaga honorer, tenaga kontrak atau sebutan lain).

Berikut faktor-faktor yang memengaruhi pengalihan kewenangan pengelolaan GTT dan PTT dari Pemerintah Kabupaten/Kota ke Pemerintah Provinsi Jawa Tengah ditinjau dari pelaksana, keuangan, peralatan, struktur organisasi dan manajemen.

\section{a. Pelaksana}

Pengalihan kewenangan pengelolaan GTT dan PTT Pendidikan Menengah dari Pemerintah Kabupaten/Kota ke Pemerintah Provinsi Jawa Tengah melibatkan jumlah personil yang sangat besar. Jumlah pegawai yang melaksanakan pengelolaan GTT dan PTT di Dinas Pendidikan dan Kebudayaan Provinsi Jawa Tengah sudah memadai.

Jumlah GTT dan PTT jenjang SMA Provinsi Jawa Tengah pada tahun 2019 berjumlah 10.090 orang dengan jumlah terbesar di Kabupaten Cilacap sebanyak 565 orang dan yang terkecil di Kota Salatiga sebanyak 90 orang. Jumlah GTT yang mengajar lebih dari 24 jam per minggu sebanyak 4.264 orang dan GTT yang mengajar kurang dari 24 jam per minggu sebanyak 1.269 orang dari jumlah total 5.533 orang. Dari jumlah total 5.533 orang tersebut, GTT dibiayai APBD sebanyak 3.476 orang dan dibiayai pendanaan swadaya masyarakat (PSM) sebanyak 2.057 orang. Sedangkan untuk PTT dibiayai oleh APBD berjumlah 3.426 orang dan dibiayai dengan pendanaan swadaya masyarakat (PSM) sebanyak 1.131 orang dari jumlah total PTT sebanyak 4.557 orang..

Jumlah GTT dan PTT jenjang SMK Provinsi Jawa Tengah Tahun 2019 berjumlah 10.080 orang dengan jumlah terbesar di Kabupaten Purbalingga sebanyak 556 orang dan terkecil jumlahnya di Kota Tegal sebanyak 76 orang. Jumlah GTT yang mengajar lebih dari 24 jam per minggu sebanyak 5.663 orang dan GTT yang mengajar kurang dari 24 jam per minggu sebanyak 636 orang dari total 6.299 orang. Dari jumlah total 6.299 orang tersebut, GTT dibiayai APBD sebanyak 4.403 orang dan dibiayai pendanaan swadaya masyarakat (PSM) sebanyak 1.896 orang. Sedangkan untuk PTT yang dibiayai oleh APBD berjumlah 
2.763 orang dan yang dibiayai dengan pendanaan swadaya masyarakat (PSM) sebanyak 1.018 orang dari jumlah total PTT sebanyak 3.781 orang.

Pada tahun 2020 jumlah GTT dan PTT jenjang SMA Provinsi Jawa Tengah berjumlah 10.263 orang dengan jumlah GTT sebanyak 2.809 orang dan PTT sebanyak 4.505 orang. Apabila dibandingkan dengan jumlah GTT dan PTT jenjang SMA pada tahun 2019 sebanyak 10.090 orang maka pada tahun 2020 jumlahnya 10.263 orang. Sedangkan jumlah GTT dan PTT jenjang SMK di Provinsi Jawa Tengah tahun 2020 berjumlah 10.329 orang dengan GTT sebanyak 6.511 orang dan PTT sebanyak 3.818 orang. GTT dan PTT jenjang SMA Provinsi Jawa Tengah pada tahun 2020 berjumlah 10.263 orang dengan jumlah GTT sebanyak 2.809 orang dan PTT sebanyak 4.505 orang. Apabila dibandingkan dengan jumlah GTT dan PTT jenjang SMA pada tahun 2019 sebanyak 10.090 orang maka pada tahun 2020 jumlahnya 10.263 orang sehingga mengalami penambahan sejumlah 173 orang (1,72\%). Sedangkan untuk jenjang SMK di Provinsi Jawa Tengah tahun 2020 berjumlah 10.329 orang dengan GTT sebanyak 6.511 orang dan PTT sebanyak 3.818 orang. Apabila dibandingkan dengan tahun 2019 maka jumlah GTT dan PTT jenjang SMK pada tahun 2019 sebanyak 10.680 orang maka pada tahun 2020 jumlahnya 10.329 orang sehingga mengalami pengurangan sejumlah 351 orang $(3,29 \%)$.

Berdasarkan Peraturan Gubernur Jawa Tengah Peraturan Gubernur Jawa Tengah Nomor 7 Tahun 2020 tentang Honorarium Bagi Guru Tidak Tetap dan Pegawai Tidak Tetap pada Sekolah Menengah Atas Negeri, Sekolah Menengah Kejuruan Negeri dan Sekolah Luar Biasa Negeri Pemerintah Provinsi Jawa Tengah maka semua GTT dan PTT yang telah memenuhi ketentuan wajib mengikat Kontrak Kerja Individu dengan Kepala Dinas Pendidikan dan Kebudayaan Provinsi Jawa Tengah.

Selain jumlah pegawai aspek lainnya yang sangat penting adalah kompetensi dimana kompetensi GTT dan PTT perlu ditingkatkan guna mendukung penyelenggaraan pendidikan menengah meskipun pada saat ini sebagai tenaga tenaga kontrak belum memungkinkan untuk peningkatan kompetensi melalui diklat. Sedangkan mentalitas pegawai salah satunya dapat dilihat dari tingkat 
kedisiplinan GTT dan PTT yang tinggi dan kinerjanya yang tinggi. Namun demikian sebagai tenaga kontrak, GTT dan PTT mengharapkan kejelasan status kepegawaian, peningkatan kesejahteraan dan kompetensi di masa mendatang

\section{b. Keuangan}

Pengalihan kewenangan pengelolaan GTT dan PTT Pendidikan Menengah

dari Pemerintah Kabupaten/Kota ke Pemerintah Provinsi Jawa Tengah membutuhkan anggaran yang sangat besar untuk honorarium GTT dan PTT yang dialihkan. Selama ini anggaran yang tersedia untuk honorarium GT dan PTT yang bersumber dari APBD Provinsi Jawa Tengah dan dana BOS belum mencukupi sehingga untuk menutupi kekurangan anggaran tersebut dengan pendanaan swadaya masyarakat. Sejak tahun 2017 sampai dengan tahun 2019 pembiayaan honorarium GTT dan PTT pendidikan menengah dari APBN (dana BOS), APBD Provinsi Jawa Tengah dan pendanaan swadaya masyarakat (PSM). Pada tahun 2020 pembiayaan honorarium GTT dan PTT pendidikan menengah dari APBN (dana BOS) dan APBD Provinsi Jawa Tengah.

Anggaran program pembinaan guru dan tenaga kependidikan pada tahun 2020 sebesar Rp. 505.798.378.000,- (17,03\%) dari total anggaran Dinas Pendidikan dan Kebudayaan Provinsi Jawa Tengah sebesar Rp. 2.970.489.077.000,-. Sedangkan pada tahun 2019 sebesar Rp. 308.489.628.000,- dari total anggaran Dinas Pendidikan dan Kebudayaan Provinsi Jawa Tengah sebesar Rp. 2.096.871.212.000,- (14,71\%). Anggaran tersebut penggunaannya sebagian besar untuk honorarium GTT dan PTT..

\section{c. Peralatan}

Pengalihan kewenangan pengelolaan GTT dan PTT Pendidikan Menengah dari Pemerintah Kabupaten/Kota ke Pemrintah Provinsi Jawa Tengah perlu dukungan peralatan. Perlatan yang berupa sarana dan prasarana untuk menunjang pelaksanaan pengelolaan GTT dan PTT sudah memadai baik di Dinas Pendidikan dan Kebadayaan Provinsi Jawa Tengah, Cabang Dinas maupun Sekolah. Peralatan ini juga didukung dengan penggunaan teknologi informatika untuk mempercepat pelayanan administrasi pengelolaan GTT dan PTT maupun pelayanan kepada publik. Untuk database GTT dan PTT yang dikoordinir oleh masing-masing 
sekolah sudah menggunakan aplikasi yang telah ditentukan oleh Dinas Pendidikan dan Kebudayaan Provinsi Jawa Tengah sehingga memudahkan dalam pelaporan. Setiap tahun dianggarkan biaya pemeliharaan peralatan dan pengadaan peralatan yang rusak.

\section{d. Organisasi dan Manajemen}

Aspek organisasi dan manajemen sangat penting dalam Pengalihan kewenangan pengelolaan GTT dan PTT Pendidikan Menengah dari Pemerintah Kabupaten/Kota ke Pemerintah Provinsi Jawa Tengah. Struktur organisasi Dinas Pendidikan dan Kebudayaan Provinsi Jawa Tengah berdasarkan Peraturan Gubernur Jawa Tengah Nomor 57 Tahun 2016 tentang Organisasi dan Tata Kerja Dinas Pendidikan dan Kebudayaan Provinsi Jawa Tengah. Dengan ditetapkannya Peraturan Menteri Dalam Negeri Nomor 12 Tahun 2017 tentang Pedoman Pembentukan Dan Klasifikasi Cabang Dinas Dan Unit Pelaksana Teknis Daerah maka Peraturan Gubernur Jawa Tengah Nomor 57 Tahun 2016 diganti dengan Peraturan Gubernur Jawa Tengah Nomor 48 Tahun 2018 tentang Organisasi dan Tata Kerja Dinas Pendidikan dan Kebudayaan Provinsi Jawa Tengah. Dalam struktur organisasi tersebut yang mengalami perubahan adalah Cabang Dinas dan Unit Pelaksana Teknis. GTT dan PTT yang ada di satuan pendidikan/sekolah yang semula di bawah koordinasi Unit Pelaksana Teknis dengan adanya perubahan struktur organisasi tersebut menjadi di bawah koordinasi Cabang Dinas sesuai wilayah kerja yang telah ditetapkan. Struktur organisasi tersebut sudah menyesuaikan dengan peraturan perundangan yang berlaku untuk mencapai tujuan yang telah ditetapkan.

Pembagian pekerjaan di Dinas Pendidikan dan Kebudayaan Provinsi Jawa Tengah berpedoman pada Peraturan Gubernur Jawa Tengah Nomor 48 Tahun 2018 tentang Organisasi dan Tata Kerja Dinas Pendidikan dan Kebudayaan Provinsi Jawa Tengah. Adapun GTT dan PTT dalam pelaksanaan tugasnya berpedoman pada job description yang telah ditetapkan oleh Dinas ataupun Sekolah. Rentang kendali pelayanan Dinas Pendidikan dan Kebudayaan Provinsi Jawa Tengah sangat luas meliputi 862 SMA, 1.585 SMK, dengan jumlah Guru SMA sebanyak 30.028 orang, Guru SMK 45.636 orang serta 404.980 siswa SMA dan 775.107 siswa SMK. 
Terkait dengan pengelolaan GTT dan PTT oleh Dinas Pendidikan dan Kebudayaan Provinsi Jawa Tengah dalam pelaksanaannya dibantu oleh Cabang Dinas untuk koordinasi dan pelaporan serta masing-masing sekolah. Dampak negatif dari pengalihan kewenangan ini adalah pelayanan administrasi yang berkaitan dengan pendidikan menengah akan kurang maksimal karena rentang kendali yang cukup jauh meliputi 35 kabupaten/kota. Selain itu diperlukan sinkronisasi dalam perencanaan dan evaluasi antara dinas dengan sekolah dalam menyusun anggaran honorarium GTT dan PTT dan evaluasi kinerjanya.

\section{Kesimpulan}

Pengalihan kewenangan pengelolaan GTT dan PTT pendidikan menengah dari Pemerintah Kabupaten/Kota ke Pemerintah Provinsi Jawa Tengah dilaksanakan dengan baik. Faktor-faktor yang memengaruhi antara lain jumlah pelaksana yang memadai dan kompetensi pelaksana sudah sesuai, ketersediaan anggaran yang memadai, ketersediaan peralatan dan teknologi yang mendukung namun karena rentang kendali Dinas Pendidikan dan Kebudayaan Provinsi Jawa Tengah yang besar dalam pelayanan administrasi pengelolaan GTT dan PTT belum optimal.

Rekomendasi untuk peningkatan pelayanan administrasi GTT dan PTT dengan memperdayakan fungsi cabang dinas pendidikan dan koordinasi intensif antara sekolah dan Cabang Dinas dengan Bidang Ketenagaan Pendidikan dan Kebudayaan. Untuk peningkatan kinerja GTT dan PTT yang merupakan tenaga kontrak maka Pemerintah diharapkan menetapkan regulasi tentang standarisasi penggajian tenaga kontrak, kejelasan status kepegawaian di masa mendatang serta pendidikan dan pelatihan dalam pengembangan kompetensi tenaga kontrak.

\section{Referensi}

Bungin, Burhan. (2012). Penelitian Kualitatif Komunikasi, Ekonomi, Kebijakan Publik, dan Ilmu Sosial Lainnya. Edisi Kedua. Jakarta: Kencana Prenada Media Group. 
Effendi, Lutfi. (2003). Pokok-pokok Hukum Administrasi Negara. Semarang: Bayumedia Publishing.

Herawati, NR. (2017). Analisis Politik Alih Kewenangan Pengelolaan Guru SMA/SMK Dari Pemerintah Kabupaten/Kota Kepada Pemerintah Provinsi. Jurnal Ilmu Sosial. Vol. 16 No. 2, Edisi Juli - Desember 2017 hal. 72-93

Hermino, Agustinus. (2014). Kepemimpinan Pendidikan Di Era Globalisasi. Yogyakarta: Pustaka Pelajar.

Kaho, Josef Riwu. (2010). Prospek Otonomi Daerah di Negara Kesatuan Republik Indonesia. Jakarta: Rajagrafindo Persada.

Moleong, Lexy J. (2009). Metodologi Penelitian Kualitatif. Bandung: PT Remaja Rosdakarya.

Nugroho, Riant. (2017). Public Policy: Teori, Manajemen, Dinamika, Analisis, Konvergensi, dan Kimia Kebijakan. Jakarta: Elex Media Komputindo.

Sarundajang, S.H. (2005). Babak Baru Sistem Pemerintahan Daerah. Jakarta: Kata Hasta.

Sendhikasari, Dewi. (2016). Pengalihan Kewenangan Manajemen Pendidikan Menengah dari Kabupaten/Kota ke Provinsi, Info Singkat, April, Pusat Penelitian Badan Keahlian DPR RI.

Setia, RE, Sulistyowati.(2019). Pengalihan Kewenangan PPendidikan Menengah Pada Dinas Pendidikan Provinsi Jawa Tengah (Studi Kasus: Tata Kelola Pendidik dan Tenaga Kependidikan). Journal of Politic and Government Studies.Vol.8 No.2 Maret 2019. pp151-160.

Sudirman, F. A., \& Phradiansah, P. (2019). Tinjauan Implementasi Pembangunan Berkelanjutan: Pengelolaan Sampah Kota Kendari. JURNAL SOSIAL POLITIK, 5(2), 291-305.

Presiden Republik Indonesia. (2014). Undang-Undang Nomor 23 Tahun 2014 Tentang Pemerintah Daerah, pada Jaringan Dokumentasi dan Informasi Hukum (JDIH) Badan Pemeriksa Keuangan (BPK) RI website: https://peraturan.bpk.go.id/Home/Details/38685/uu-no-23-tahun-2014. 